\title{
Pendampingan Anak-anak Usia Sekolah dalam Rangka Implementasi Hypnoteaching untuk Meningkatkan Motivasi Belajar Matematika di Kuala Langsa
}

\section{Mentoring School-Age Children in the Framework of Hypnoteaching Implementation to Improve Mathematics Learning Motivation in Kuala Langsa}

\author{
Rizki Amalia*, Muhammad Zaki, Sofiyan \\ *Universitas Samudra, Email: rizkiamalia@unsam.ac.id
}

\begin{abstract}
Abstrak
Pengabdian masyarakat ini menitikberatkan pada pengajaran baik berupa materil maupun moril untuk meningkatkan motivasi belajar anak-anak khususnya di Kuala Langsa. Berdasarkan analisis situasi yang berkembang saat ini, permasalahan utama yang dihadapi yaitu: (1) Kurangnya minat anak-anak usia sekolah di daerah Kuala Langsa untuk bersekolah; (2) Rendahnya motivasi anakanak usia sekolah di daerah Kuala Langsa untuk belajar matematika; dan (3) Mata pelajaran matematika menjadi momok yang menakutkan dan mata pelajaran yang membosankan karena bersifat abstrak dan tidak ada media atau alat peraga yang real. Pada tahapan persiapan, tim pelaksana melakukan observasi di SD Negeri 9 Langsa dan kantor kepala desa Kuala Langsa. Observasi dilakukan untuk mengetahui masalah apa yang dihadapi anak-anak usia sekolah terutama SD dalam pembelajaran Matematika dan motivasi untuk pergi menuntut ilmu ke sekolah. setelah diketahui permasalahannya maka disusun suatu solusi untuk diterapkan dalam tahap pelaksanaan. Proses pelaksanaan terbagi menjadi : (1) Sosialisasi (memberikan motivasi belajar anak-anak terutama matematika dan menekankan pentingnya bersekolah) dan (2) Praktek Lapangan (penerapan metode Hypnoteaching). Kesimpulan yang diperoleh adalah: (1) Tingkat partisipasi mitra yang tinggi terhadap program pengabdian masyarakat memberikan dampak yang positif terhadap pelaksanaan program; dan (2) Pelaksanaan program pengabdian ini mampu meningkatkan pengetahuan serta minat belajar anak anak dalam mata pelajaran matematika, khususnya pada materi bangun datar. Dengan demikian akan menunjang nilai- nilai dan motivasi belajar siswa pada mata pelajaran matematika.
\end{abstract}

Kata kunci:. Hypnoteaching, Motivasi Belajar.

\section{Abstract}

This community service focuses on teaching both material and moral to increase children's learning motivation, especially in Kuala Langsa. Based on an analysis of the current situation, the main problems faced are: (1) Lack of interest in school-age children in Kuala Langsa to attend school; (2) Low motivation for school-age children in the Kuala Langsa area to study mathematics; and (3) Mathematical subjects become a frightening specter and subjects are boring because they are abstract and there are no real media or teaching aids. At the preparation stage, the implementing team conducted observations at SD Negeri 9 Langsa and the office of the village head of Kuala Langsa. Observations were made to find out what problems faced by school-age children, especially elementary schools, in learning mathematics and the motivation to go to school. after the problem is known, a solution is prepared to be implemented in the implementation phase. The implementation process is divided into (1) Socialization (providing children's learning motivation, especially mathematics and emphasizing the importance of schooling) and (2) Field Practice (applying Hypnoteaching methods). The conclusions obtained are: (1) The high level of participation of partners in community service programs has a positive impact on program implementation; and (2) The implementation of this service program is able to increase the knowledge and interest in learning of children in mathematics subjects, especially in the flat-building material. Thus it will support students' values and learning motivation in mathematics subjects.

Key words: Hypnoteaching, Motivation to learn. 


\section{PENDAHULUAN}

Menurut Undang-Undang Republik Indonesia Nomor 12 Tahun 2012 Tentang Perguruan Tinggi, pengabdian kepada masyarakat adalah kegiatan civitas akademika yang memanfaatkan ilmu pengetahuan dan teknologi untuk memajukan kesejahteraan masyarakat dan mencerdaskan kehidupan bangsa. Berdasarkan pernyataan undang-undang tersebut, pengabdian masyarakat merupakan salah satu tugas pokok Perguruan Tinggi yang melibatkan segenap civitas akademika, termasuk di dalamnya adalah dosen dan mahasiswa. Pernyataan undang-undang tersebut juga sekaligus mengindikasikan bahwa sudah seharusnya dosen dan mahasiswa memiliki kesadaran untuk peduli dan berkontribusi nyata dalam pembangunan nasional. Oleh karena itu, tim merencanakan untuk mengadakan kegiatan pengabdian masyarakat ke daerah Kuala Langsa.

Langsa merupakan daerah yang memiliki pelabuhan yaitu Kuala Langsa. Anak-anak di daerah pesisir Kuala Langsa pada umumnya tidak menekankan pada faktor pentingnya bersekolah.

Pengabdian masyarakat ini menitikberatkan pada pengajaran baik berupa materil maupun moril untuk meningkatkan motivasi belajar anak-anak khususnya di Kuala Langsa. Hal ini didasari oleh kenyataan bahwa sebagian besar anakanak malas atau enggan untuk belajar, terutama pelajaran matematika. Misalnya ketika kegiatan tutorial/les di Sekolah, sebagian anak-anak sering terlambat datang, bahkan banyak juga yang tidak hadir. Di lain pihak, sering kita dengar keluh kesah dari guru bahwa siswa banyak yang kurang disiplin dan perhatiannya sangat rendah pada pelajaran. Motivasi siswa cenderung sekadar mencari naik kelas, lulus, tetapi tidak mau belajar secara optimal. Selain itu, faktor yang paling sering mengakibatkan matinya semangat belajar anak-anak adalah anggapan bahwa pelajaran tersebut tidak berguna untuk masa depannya. Anggapan bahwa pelajaran itu susah juga turut mengakibatkan rendahnya keinginan anakanak untuk rajin belajar sehingga menyebabkan terhambatnya perkembangan anak.

Paradigma bahwa matematika adalah suatu ilmu pengetahuan yang sulit dan tidak menarik masih aktual hingga saat ini. Hal ini ditunjukkan dengan rata-rata nilai Ujian Nasional yang selalu rendah untuk bidang studi matematika. Hal tersebut menjadi salah satu indikator sulitnya matematika di kalangan para siswa. Hal ini menjadi lebih memprihatinkan ketika anak-anak didik, misalnya anak di Kuala Langsa yang tidak mendapat tambahan tutorial atau diskusi dari soal-soal matematika yang didapat dari sekolah. Kondisi ini menambah ketidaktahuan mereka terhadap materi yang terus berkembang sehingga lama kelamaan akan memunculkan rasa acuh dan malas bahkan jenuh terhadap pelajaran matematika.

Pada pengabdian masyarakat ini tim berupaya memotivasi minat anak agar senang dengan pelajaran matematika. Kegiatan metode hypnoteaching ini mencakup pemberian motivasi anak, materi terkait pelajaran matematika dan aplikasinya dalam kehidupan sehari-hari serta bermain sambil belajar melalui media atau alat peraga edukasi yang membuat belajar matematika lebih menyenangkan.

Adapun tujuan diselenggarakannya program pengabdian kepada masyarakat ini adalah sebagai berikut.

1. Menumbuhkembangkan budaya peduli dan peka bagi dosen dan mahasiswa pendidikan Matematika Universitas Samudra;

2. Memberikan persepsi pentingnya untuk menuntut ilmu ke sekolah; dan

3. Meningkatkan motivasi belajar matematika bagi anak-anak daerah Kuala Langsa juga memperkenalkan asyiknya belajar matematika melalui media atau alat peraga.

Atas dasar itulah tim ingin melakukan pengabdian ini. Kegiatan ini merupakan suatu bentuk bantuan yang 
walaupun kecil namun sangat berguna untuk anak-anak di Kuala Langsa yang juga merupakan calon penerus tongkat estafet pembangunan nasional ini.

\section{SOLUSI/TEKNOLOGI}

Secara umum kegiatan pengabdian kepada masyarakat ini bertujuan untuk meningkatkan motivasi belajar matematika dan menekankan pentingnya sekolah bagi anak-anak usia sekolah daerah Kuala Langsa. Sehubungan dengan hal ini, maka khalayak sasaran yang strategis adalah dikhususkan kepada anak-anak Sekolah Dasar (SD) di daerah Kuala Langsa.

Berdasarkan atas pertimbangan biaya dan ketersediaan sarana dan prasarana maka pada saat ini diputuskan untuk menyelenggarakan pendampingan ini untuk anak-anak SD kelas V dan VI di SD Negeri 9 Langsa sebagai rekomendasi dari kepala desa Kuala Langsa dan Kepala Sekolah dan guru di SD Negeri 9 Langsa.

Adapun metode pelaksanaan kegiatan pengabdian ini menggunakan metode pendekatan secara langsung, ceramah dan praktik. Adapun tahapan yang dilakukan dalam pelaksanaan kegiatan ini meliputi:

\section{a. Tahapan Persiapan}

Dalam tahapan persiapan ini, tim pelaksana kegiatan pengabdian kepada masyarakat melakukan observasi di SD Negeri 9 Langsa dan pada kantor kepala desa Kuala Langsa. Observasi dilakukan untuk mengetahui masalah apa yang dihadapi anak-anak usia sekolah terutama SD dalam pembelajaran Matematika dan motivasi untuk pergi menuntut ilmu ke sekolah. setelah diketahui permasalahannya maka disusun suatu solusi untuk diterapkan dalam tahap pelaksanaan.

\section{b. Pelaksanaan}

Proses pelaksanaan terbagi menjadi dua bagian, yaitu:

a) Sosialisasi
Tahap ini bertujuan untuk memberikan motivasi belajar anak-anak terutama matematika dan menekankan pentingnya bersekolah.

b) Praktek Lapangan

Dalam praktek lapangan akan dilakukan penerapan metode Hypnoteaching di sekolah. Rincian kegiatan penerapan metode Hypnoteaching secara garis besar sebagai berikut.

1. Setiap anak dibuat kelompok belajar yang pelaksanaannya di ruang kelas di sekolah. Anakanak diberikan pandangan pentingnya sekolah agar anakanak dapat semangat dan memiliki keinginan untuk bersekolah sebaik mungkin. Anak-anak juga diberikan motivasi agar matematika tidak lagi menjadi momok yang menakutkan dan membosankan.

2. Selanjutnya diterapkan metode Hypnoteaching dengan menyesuaikan langkahlangkah yang sesuai dan menggunakan media atau alat peraga yang menarik dan memudahkan mereka untuk belajar.

3. Dilakukan evaluasi dan refleksi pada setiap akhir pelaksanaan kegiatan.

4. Pada akhirnya dilakukan pendampingan dengan cara mengunjungi beberapa anak untuk melihat perkembangan sekolahnya. Namun, karena keadaan tidak memungkinkan, pendampingan dilakukan dengan mengadakan tutorial/les di kelas di SDN 9 Langsa/Balai Kepala desa Kampung Kuala Langsa setiap sabtu pada pukul 14.00 WIB.

\section{c. Evaluasi Kegiatan}


Keberhasilan pelaksanan pengabdian kepada masyarakat yang diusulkan ini akan dievaluasi selama pelaksanaan berjalan. Evaluasi awal dilakukan oleh tim pelaksana dalam dua hal kegiatan, yaitu:

1. Kegiatan inti pada saat peserta menerima Hypnoteaching penerapan

2. Diluar kegiatan inti, yaitu kegiatan pendampingan yang dilakukan setiap minggu setelah tim pelaksana melaksanakan kegiatan pengabdian kepada masyarakat. Hal ini dilakukan untuk mengecek kembali bagaimana motivasi peserta bersekolah.

\section{HASIL DAN DISKUSI}

Kegiatan awal pada program pengabdian kepada masyarakat ini adalah mengobservasi lokasi dan sasaran pengabdian di Desa Kuala Langsa dan SD Negeri 9 Langsa. Awalnya Tim Pengabdian masyarakat menjajaki tentang kesedian bekerjasama untuk melakukan program pengabdian ini dengan Kepala desa Desa Kuala Langsa dan Ibu Kepala Sekolah SD 9 Langsa. Kepala desa dan Kepala SD Negeri 9 Langsa menyambut baik kegiatan ini.

Selain itu, tim pengabdian yang terdiri dari tiga dosen prodi Pendidikan Matematika Unsam dan beberapa mahasiswa prodi juga memperoleh informasi bahwa penghasilan orang tua siswa di desa Kuala Langsa adalah didominasi oleh pelaut ditambah dengan penghasilan swasta lainnya. Dari hasil pendataan yang diperoleh oleh tim pengabdian bahwa anak-anak desa atau desa Kuala Langsa bersekolah terdekat, yaitu di SD Negeri 9 Langsa yang berjarak sekitar 20 meter dari kantor Kepala desa Kuala Langsa. Jadi, tim pengabdian setelah berdiskusi dan memperoleh informasi dari Kepala desa Kuala Langsa, langsung menuju ke Sekolah Dasar Negeri 9 Kuala Langsa.
Kemudian kegiatan dilanjutkan diskusi tentang berbagai permasalahan yang berkembang saat ini yang terkait motivasi dan kesadaran belajar anak-anak desa atau desa Kuala Langsa. Terkait permasalahan tersebut, ada beberapa permasalahan yang telah disepakati bersama untuk segera ditangani oleh tim pengabdian, yaitu: (1) kurangnya minat anak-anak usia sekolah di daerah Kuala Langsa untuk bersekolah. Mereka lebih mementingkan mencari uang lebih dengan kerjaan sampingan dari memancing dan sebagainya; (2) rendahnya motivasi anak-anak usia sekolah di daerah Kuala Langsa untuk belajar matematika; dan (3) mata pelajaran matematika menjadi momok yang menakutkan dan mata pelajaran yang membosankan karena bersifat abstrak dan tidak ada media atau alat peraga yang real.

Beranjak dari permasalahan yang sudah disepakati di atas, Tim pengabdian masyarakat telah menyusun sebuah program kegiatan dengan judul "Pendampingan Anak-Anak Usia Sekolah Dalam Rangka Implementasi Hypnoteaching Untuk Meningkatkan Motivasi Belajar Matematika Di Kuala Langsa". Adapun anak-anak yang menjadi sasaran program pengabdian ini adalah anak-anak berusia Sekolah kelas V dan Kelas VI. Kegiatan ini dilaksanakan di SD Negeri 9 Langsa yang berlokasi di desa Kuala langsa, bersebelahan dengan Mesjid dan Kantor Kepala desa Kuala Langsa.

Peserta yang terlibat pada kegiatan ini adalah anak-anak desa Kuala Langsa berusia sekolah kelas V dan VI. Kemudian Tim pengabdian diantaranya dua orang dosen Prodi Pendidikan Matematika Rizki Amalia, S. Pd,. M. Pd dan Muhammad Zaki, S. Pd,. M. Pd, serta 5 orang mahasiswa prodi Pendidikan Matematika FKIP UNSAM.

Kegiatan implementasi Hypnoteaching dilaksanakan pada hari Rabu dan Kamis tanggal 12 dan 13 September 2018 di SD Negeri 9 Langsa. Kegiatan awal yang dilakukan adalah pengenalan Tim 
pengabdian dan pemberian motivasi kepada siswa.

Hari pertama kegiatan pengabdian ini adalah diawali dengan penyampaian materi oleh Rizki Amalia, S. Pd,. M. Pd dan selanjutnya Muhammad Zaki, S.Pd.I, M. Pd. Pemateri menekankan pada motivasi kepada anak-anak untuk terus belajar matematika dengan memberikan treatment atau mengimplementasikan Hypnoteaching. Pemateri mencoba menginspirasi dan mengsugesti anak-anak dengan cerita-cerita tentang matematika, sejarah dan perkembangan matematika, serta urgensinya belajar matematika. Meskipun anak-anak pada awalnya belum dilibatkan dalam aktivitas matematika seperti memperagakan suata benda sebagai alat bermain sekaligus sumber belajar tetapi anak-anak sangat antusias. Pemateri memberikan treatment yang sesuai dengan kondisi siswa, usia, dan taraf berpikir anak-anak. Tahap ini disebut tahap pacing dimana pemateri telah menyamanakan gerak tubuh dan bahasa dengan siswa.

Kemudian tahap berikutnya pada implementasi hypnoteaching adalah leading. Pemateri telah mengontrol dan mengarahkan anak-anak pada sesuatu sehingga anak-anak tetap tetap fokus dan merasa nyaman dengan suasana yang sudah dibuat. Pada tahap ini juga suasana kelas bertambah ceria dan bersemangat setelah pemateri mencoba mengselipkan kegiatan pendampingan ini dengan putaran video pendek inspiratif untuk anak usai kelas V dan VI. Materi pada implementasi Hypnoteaching adalah materi Bangun Datar. Pada hari Rabu tanggal 12 September 2018 dilaksanakan kegiatan pengenalan Bangun Datar pada siswa kelas $\mathrm{V}$ dan VI di SD Negeri 9 Langsa yang dilakukan melalui alat peraga menggunakan kertas origami. Siswa dibentuk kelompok dengan teman sebangku. Kemudian tim memberikan arahan bagaimana cara membuat berbagai bentuk bangun datar dengan kertas origami. Selanjutnya memberikan tantangan dalam membuat bangun datar sesuai dengan gambar tanpa diawali arahan tim lagi. Diskusi dan kegiatan coba-coba siswa tersebut meningkatkan keingintahuan siswa terhadap jenis-jenis bangun datar.

Anak-anak dilibatkan untuk melakukan aktivitas matematika memanipulasikan benda konkret sebagai sumber belajar matematika. Mereka belajar mengenal bangun datar dengan melakukan manipulasi kertas origami warna-warni. Anak-anak sangat menikmati kegiatan ini pada saat melakukan aktivitas matematika memanipulasi kertas-kertas menjadi bangun datar dan, ekspresi anak-anak sangat senang, meskipun kadang riuh tepatnya pada saat berlomba-lomba melakukan aktivitas matematika. Anak-anak melakukan aktivitas mengkonstruksi bangun datar secara tidak sadar, awalnya seperti bermain.

Selanjutnya pada hari kamis tanggal 13 September 2018 dilanjutkan dengan materi Luas dan Keliling Bangun Datar melalui Implementasi Hypnoteaching. Materi diberikan melalui metode penemuan sehingga siswa lebih ingat terhadap materi. Implemenatsi hyonoteaching ini juga menerapkan adanya yelling. Ketika siswa sedang melakukan aktivitas matematika dengan penuh semangat, suasana anak-anak sedang sangat riuh, maka pemateri meneriakkan dengan istilah tertentu tujuannya adalah untuk mengembalikan kosentrasi anak-anak pada materi. Teriakan ini juga disahut oleh siswa secara bersamasama. Tahap yeeling ini sebelumnya telah diintruksikan kepada anak-anak dan untuk disepakati bersama.

Selain itu kegiatan pendampingan anak-anak ini juga diselingi dengan memberikan pujian dan reward yang diberikan kepada anak-anak. Pemateri memberikan pujian dan rewad untuk menumbuhkan konsep diri, semangat dan kepercayaan diri anak.

Kegiatan ini terus berlanjut dengan pendampingan yang dilaksanakan untuk anak-anak Desa Kuala Langsa yang berusia Sekolah Dasar kelas V dan Kelas VI di SD Negeri 9 Langsa diluar jam sekolah. Kegiatan ini dilaksanakan setiap hari sabtu dimulai tanggal 15 September 2018 
bertempat di SDN 9 Langsa atau di Balai Kepala desa Desa Kuala Langsa. Berlangsung mulai pukul 14.00 WIB sampai 15.30 WIB.

$$
\text { Pada hakikatnya metode }
$$

Hypnoteaching merupakan perpaduan dari konsep aktivitas belajar mengajar dengan ilmu hipnotis. Dengan pengertian bahwa pembelajaran tersebut berpusat pada pikiran bawah sadar siswa melalui sugesti sehingga menumbuhkan kondisi yang menyenangkan. Menurut Noer (2010), dalam Hypnoteaching, guru berperan sebagai hipnotis sementara siswa selaku orang yang dihipnotis. Guru selaku penghipnotis tidak perlu menidurkan siswa dalam proses pembelajaran, namun cukup dengan menggunakan bahasa persuasif sebagai alat komunikasi yang dapat mensugesti siswa secara efektif.

Hypnoteaching berasal dari kata "hypnosis" yang berarti sugesti dan "teaching" yang berarti mengajar. Menurut Hajar (2011: 45) sugesti merupakan kondisi psikologis di mana seseorang membimbing pikiran, perasaan atau perilaku orang lain dengan kata-kata. Metode hypnoteaching merupakan suatu cara yang memudahkan seseorang untuk menyerap informasi secara cepat tanpa adanya tekanan, ego, dan kecemasan atau dapat dikatakan apabila seseorang masuk dalam kondisi hipnotis maka semakin lama orang tersebut akan semakin sugestif (Hakim, 2011: 13- 14). Lebih lanjut Hakim (2011) menyatakan bahwa Hypnoteaching merupakan gabungan dari lima metode belajar mengajar seperti quantum learning, accelerate learning, power teaching, Neuro-Linguistic Programming (NLP) dan hypnosis. Metode hypnoteaching ini pada dasarnya mengajak pikiran untuk rileks, meditatif, terkendali, fokus, akses ke bawah sadar, dan super learning sehingga materi yang dipelajari mudah diserap oleh siswa (Sari, 2011: 25).

Hypnoteaching merupakan ilmu yang di dalamnya terdapat langkah-langkah dalam penggunaannya, hal ini merupakan titik puncak pada aplikasi model pembelajaran tersebut. Menurut Muhammad Noer (N.Yustisia, 2012: 85-91), dalam hypnoteaching ada beberapa langkah yang perlu di lakukan. Langkah-langkah tersebut sebagai berikut :

a) Niat dan Motivasi dalam diri, Kesuksesan seseorang tergantung dengan pada niatnya untuk senantiasa berusaha dan bekerja keras dalam mencapai kesuksesan. Niat yang besar dan tekad yang kuat akan menumbuhkan motivasi dan komitmen yang tinggi bidang yang tengah ditekuni.

b) Pacing, berarti menyamakan posisi, gerak tubuh, bahasa, serta gelombang otak dengan orang lain atau siswa. Sebab, pada prinsipnya manusia cenderung lebih suka berinteraksi dengan teman yang memiliki banyak kesamaan.

c) Leading, berarti memimpin atau mengarahkan sesuatu. Hal ini dilakukan setelah proses pacing dilakukan. Di langkah ini lah suasana hipnotis itu terjadi. Peserta didik akan merasa nyaman dengan suasana pembelajaran yang berlangsung. Ketika itulah hampir setiap apapun yang diucapkan oleh guru atau ditugaskan pada peserta didik, peserta didik akan melakukan dengan suka rela dan senang hati. Meskipun materi yang dihadapi sulit, pikiran bawah sadar peserta didik akan menangkap materi pelajaran yang di sampaikan guru menjadi hal yang mudah.

d) Menggunakan kata-kata positif, Langkah ini merupakan langkah pendukung dalam melakukan pacing dan leading. Penggunaan kata positif ini sesuai dengan cara kerja pikiran bawah sadar yang tidak mau menerima kata-kata negatif. Guru sebaiknya mengunakan katakata positif untuk mengganti katakata yang negatif. Misalnya, ketika peserta didik di kelas ribut dan gaduh, guru tidak boleh mengatakan "jangan ribut", tetapi diganti dengan mengatakan "mohon tenang". 
e) Berikan pujian, Salah satu hal penting yang harus diingat oleh guru adalah adanya reward and punishment dalam proses pembelajaran. Pujian adalah reward peningkatan harga diri seseorang. Pujian ini merupakan salah satu konsep diri seseorang. Sementara punishment merupakan hukuman atau peringatan yang diberikan guru ketika peserta didik melakukan sesuatu tindakan yang kurang sesuai. Namun, guru harus bijak dan hati-hati dalam memberi punishment agar tidak membuat peserta didik rendah diri dan tidak bersemangat.

f) Modelling, Modelling merupakan proses pemberian teladan atau contoh melalui ucapan dan perilaku. Hal ini merupakan sesuatu yang sangat penting dan menjadi salah satu kunci berhasil atau tidaknya hypnoteaching. Setelah peserta didik merasa nyaman dengan guru dan suasana pembelajaran, diperlukan pula kepercayaan peserta didik pada guru yang dimantapkan melalui perilaku dan ucapan yang konsisten dari guru. Hal ini akan membuat guru menjadi sosok yang bisa dipercaya di mata peserta didik.

Menurut Uno (2010:65) metode pembelajaran merupakan cara-cara yang digunakan pengajar atau instruktur untuk menyajikan informasi atau pengalaman baru, menggali prestasi belajar, menampilkan unjuk kerja peserta belajar dan lain-lain. Hal senada diutarakan oleh Abdul Hamid (2009:53) Metode pembelajaran adalah cara-cara yang berbeda untuk mencapai hasil pembelajaran yang berbeda dalam kondisi yang berbeda. Hypnoteacing sendiri memiliki langkahlangkah agar sebuah informasi atau pengalaman baru dapat diserap oleh siswa. Secara garis besar menurut Aris Setiawan, hypnoteaching memiliki enam langkah langkah-langkah dasar : (1). Niat dan motivasi dalam diri guru, (2). Mengaktifkan pikiran bawah sadar, (3). Leading (memimpin), (4). Penggunaan kata-kata positif, (5). Pemberian pujian, (6). Modelling.

Berangkat dari buku Accelerated Learning for the $21^{\text {st }}$ century, karangan Colin Rose dan Malsom. Andri Hakim (2010:152-154) mengemukakan enam langkah jitu untuk membuka kunci pikiran utama anda yang singkat dengan 'M.A.S.T.E.R' menjelaskan bagaimana rencana sederhana bisa menjadi kunci keberhasilan kepada seseorang. Setiap siswa, orang tua, dan guru yang mengajar harus memahami keenam langkah tersebut untuk mempercepat proses pembelajaran.

Langkah 1: Mind (menciptakan ketenangan dalam berpikir). Lingkungan kelas dari guru, ruangan kelas, ruangan di luar kelasharus saling sinergi untuk memberi ketenangan kepada pikiran siswa.

Langkah 2: Acquiring the fact (memperoleh fakta). Pada proses belajar-mengajar, seseorang siswa memerlukan contoh-contoh dan fakta dalam kehidupan sehari-hari. Sebagai contoh, mengapa siswa harus belajar kimia bisa dijelaskan secara fakta bahwa bahan baku sabun mandi, sampo, dan semacamnya merupakan merupakan hasil dari reaksi kimia. Begitu juga komposisi tubuh kita.

Langkah 3: Search Out The Meaning (Menemukan arti yang sebenarnya), sebaiknya seorang guru bisa memberikan analogi dan penjelasan yang realistis terhadap maksud dan tujuan dari setiap materi pelajaran. Dengan demikian, pikiran siswa menerima dan memahami maksud dari setiap materi yang diterangkan dengan cepat.

Langkah 4: Trigger the Memory (Memicu memori siswa). Seorang guru harus mampu membangkitkan rasa ingin keingintahuan siswa dengan memberikan penjelasan detail yang lebih menarik. Pertanyaan bisa dibuat semenarik mungkin dalam bentuk permainan pertanyaan bersantai. Secara otomatis, hal itu memicu setiap murid untuk bertanya dan memicu memorinya untuk merecall atau memanggil informasi di memori pikiran siswa. 
Langkah 5: Exhibit (Memeragakan). Seseorang guru harus mampu memberikan contoh secara nyata atau dengan melatih soal-soal yang membantu siswa untuk memahami dan meneladani materi pelajaran, ingat, dalam sebuah proses pembelajaran apa yang telah dipelajari. Sebuah ujian atau latihan soal adalah pencerminan dari keandalan siswa dalam memeragakan apa yang telah ia pelajari.

Langkah 6: Reflect (merefleksikan apa yang telah dipelajari). Seseorang guru harus bisa menyimpulkan dan merefleksikan materi pelajaran yang baru diterangkan, hal ini memudahkan siswa untuk mengingat dan memahami materi pelajaran yang baru diperoleh. Seorang guru harus bisa memperhatikan refleksi dari siswa ketika siswa belum memahami apa yang telah diterangkan oleh guru."

Jadi Solusi permasalahan yang dilaksanakan pada program pengabdian kepada masyarakat ini adalah:

1) Mengubah paradigma berpikir anakanak SD di daerah Kuala Langsa terhadap pentingnya sekolah, menuntut ilmu sebagai modal aplikasinya dalam kehidupan;

2) Memotivasi anak-anak SD di daerah Kuala Langsa terhadap minat belajar Matematika yang sulit dan menakutkan melalui konsep belajar matematika yang menyenangkan;

3) Menerapkan metode Hypnoteaching pada anak-anak SD di daerah Kuala Langsa; dan

4) Memberikan pengalaman serta penguatan ingatan dalam mempelajari Matematika dengan menghadirkan tantangan secara intelektual.

\footnotetext{
Kesimpulan yang diperoleh dari pelaksanaan program pengabdian masyarakat ini adalah :

1. Tingkat partisipasi mitra yang tinggi terhadap program pengabdian masyarakat memberikan dampak yang positif terhadap bagi pelaksanaan
}

Pengabdian kepada Masyarakat (PkM); dan

2. Pelaksanaan program pengabdian ini mampu meningkatkan pengetahuan serta minat belajar anak - anak dalam mata pelajaran matematika, khususnya pada materi bangun datar. Dengan demikian akan menunjang nilai- nilai dan motivasi belajar siswa pada mata pelajaran matematika.

Dalam pelaksanaan program pengabdian ini, terlihat pihak SDN 9 Langsa dan siswa sangat bersemangat dalam mengikuti rangkaian kegiatan yang diadakan oleh Tim pelaksana. Hal-hal yang perlu diperhatikan dan dipertimbangkan, yaitu :

1. Bagi anak - anak yang telah mendapatkan pengetahuan terkait pembelajaran matematika yaitu melalui Implementasi Hypnoteaching, hendaknya dapat mengeksplorasi pengetahuannya dengan terus mengasah kemampuannya, sehingga mampu menyelesaikan masalah - masalah yang terkait.

2. Perlunya perhatian khusus dari semua kalangan untuk dapat memberikan dukungan dan arahan terhadap perkembangan anak- anak, khususnya perhatian yang terkait dengan pendidikan.

\section{UCAPAN TERIMA KASIH}

Tim Pelaksana PkM mengucapkan terima kasih kepada LPPM Universitas Samudra yang telah membiayai kegiatan ini melalui anggaran DIPA Universitas Samudra. Tim Pelaksana juga mengucapkan terimakasih kepada SD Negeri 9 Langsa dan Kepala Desa Kuala Langsa.

\section{PUSTAKA}

Al-Hadad, Rohdian. 2017. Kitab Rahasia Seni Hypnoteaching. Cirebon: LovRinz Publishing.

Rima, Ega dan Shinta Kusuma. 2016. Menjadi Guru Hebat dengan 
Hypnoteaching. Kata Pena.

Al Krismanto, 2003. Beberapa

Teknik,Model, Dan Strategi Dalam

Pembelajranan Matematika,

Yogyakarta, Departemen

Pendidikan Nasional, Direktorat

Jenderal Pendidikan Dasar Dan

Menengah, Pusat Pengembangan

Penataran Guru Matematika.

Budiarso Singgih, Aris. 2016. Pengembangan Bahan Ajar Berbasis Metode Hypnoteaching untuk Memotivasi Siswa SMP dalam Belajar IPA pada Materi Energi Terbarukan. Jember : Jurnal Pena Sains Vol. 3, No. 2.
Hakim, A 2011. Hypnosis in Teaching, Jakarta: Visimedia.

Noer, Muhammad. 2010. Hypnoteaching for Success Learning, Yogyakarta: Pedagogia.

Sukmadinata, Nana Syaodih. 2005. Metode Penelitian. Bandung: Remaja Rosdakarya.

Wati, Ega Rima dan Shinta Kusuma. 2016. Menjadi Guru Hebat dengan Hypnoteaching. Jakarta: Kata Pena.

Yustisia, N. 2012. Hypnoteaching. Yogyakarta: Ar-Ruzz Media 